\title{
Systemic Acquired Resistance
}

\section{Scott Uknes, Bernard Vernooij, Shericca Williams, Danielle Chandler, Kay Lawton, Terrance Delaney, Leslie Friedrich, Kris Weymann, David Negrotto, Thomas Gaffney, Manuela Gut-Rella ${ }^{1}$, Helmut Kessmann', Danny Alexander, Eric Ward, and John Ryals Agricultural Biotechnology, Ciba-Geigy Corporation, Research Triangle Park, NC 27709}

\section{SYSTEMIC ACQUIRED RESISTANCE}

Diseases of plants often limit crop quality, quantity, and choice. We have been investigating manipulation of systemic acquired resistance (SAR) — one of a plant's natural defense systems - to relieve these problems. This natural phenomenon of resistance development in response to prior pathogen infection, initially called plant immunity, was recognized in the early 1900 s. In 1933, Chester reviewed research on "acquired physiological immunity in plants" and suggested its general importance for " the preservation of plants in nature" (Chester, 1933). However, the first systematic study of SAR was published by Ross (1961b), who infected xanthi-nc tobacco (Nicotiana tabacum L.) (local lesion host) with tobacco mosaic virus (TMV) and found that subsequent infections were reduced in severity. He termed the resistance that developed in the distal, untreated portions of TMVinoculated plants "systemic acquired resistance" (Ross, 1961b). Resistance in the same leaf that had been TMV-inoculated was called "local acquired resistance" (LAR) (Ross, 1961a). Treatments, such as wounding or applying phytohormones, had no significant effect on the development of SAR (Uknes et al., 1993a; unpublished data). Others, including Kuc (1982), extended work on SAR to nonviral pathogens and the field (for review, see Kessmann et al., 1994). In addition, several synthetic chemicals, such as 2,6-dichlorisonicotinic acid(INA), can activate the same spectrum of resistance in plants while exhibiting no direct antimicrobial activity (Kessmann et al., 1994).

SAR appears to be a ubiquitous phenomenon of higher plants and has been demonstrated, for example, in soybean (Glycine max L.), potato (Solanum tuberosum L.), tomato (Lycopersicon esculentum Mill.), pearl millet (Pennisetum glaucum L.), alfalfa (Medicago sativa L.), cucurbits (Cucurbita spp.), green bean (Phaseolus vulgaris L.), Arabidopsis thaliana, rice (Oryza sativa L.), and barley (Hordeum vulgare L.), as well as other plants (for review, see Kessmann et al., 1994).

\section{SAR IS CORRELATED WITH SPECIFIC GENE EXPRESSION}

Many of the so-called "defense responses" that are induced by pathogen infection (e.g., expression of certain genes, phytoalexin accumulation, cell wall cross-linking) are only induced locally, near the pathogen (Lamb et al., 1989). Therefore, these responses are not associated with the resistant state found in the noninoculated portion of the infected plant. Van Loon and Antoniw (1982) demonstrated that a subset of the pathogenesis-related proteins (PR proteins), the acidicextracellular forms in tobacco, accumulate during the onset of resistance. More recently, steady-state mRNA levels from at least nine families of genes were coordinately induced in uninfected, resistant leaves of inoculated plants; these gene families are now known as "SAR (systemic acquired resistance) genes" (Ward et al., 1991). Several of the SAR genes encode proteins that are similar to proteins, with direct antimicrobial activity. These activities include $\beta-1,3-$ glucanases, chitinases, and cysteine-rich proteins related to thaumatin (for review, see Kessmann et al., 1994). Direct evidence for SAR gene involvement in resistance comes from experiments showing that constitutive high-level expression of tobacco PR-1a in transgenic tobacco (Nicotiana tabacum cv. Xanthi nc) results in increased tolerance to two oomycete pathogens, Peronospora tabacina Adam (causal agent of blue mold disease) and Phytophthora parasitica (black shank

Received for publication 1 Feb. 1995. Accepted for publication 16 Feb. 1995 ${ }^{1}$ Ciba-Geigy, CH-4002 Basel, Switzerland. disease) (Alexander et al., 1993). These two pathogens are effectively controlled by SAR, and PR-1 is the most abundant protein associated with the resistant state.

Support for the involvement of SAR gene homologs in resistance comes from experiments with transgenic tobacco and Brassica seedlings that express a chitinase from bean; these plants are significantly protected against damping-off caused by Rhizoctonia (Broglie et al., 1991). We have observed similar resistance to Rhizoctonia in tobacco transformed with acidic and basic chitinases from tobacco and cucumber (Cucumis sativus L.) (Uknes et al., unpublished data).

Although several SAR genes apparently are common among plants, each species seems to have evolved a distinct subset of SAR genes. For example, PR-1 is the most abundant SAR gene in tobacco, but an acidic class III chitinase is most abundant in cucumber (Métraux et al., 1988; Ward et al., 1991). Although not proven, such differences may reflect differences in evolutionary or breeding constraints that have selected for the most effective SAR response to the particular pathogen spectrum to which the host is subject. Therefore, plants apparently have developed an inducible pyramid of defenses, a likely evolutionarily stable form of resistance.

Microscopic studies have shown that plants exhibiting SAR appear to mimic the type of resistance observed with dominant genetic resistance. This response is demonstrated as increased deposition of papilla-like material and a hypersensitive-like response, indicated by rapid plant cell death at the attempted site of penetration (Dean and Kuc, 1988; Stein et al., 1993; Uknes et al., 1992, 1993b).

\section{SALICYLIC ACID AS A SIGNAL FOR SAR}

In 1979, White showed that the exogenous application of salicylic acid (SA) and certain other benzoic acid derivatives could induce resistance to TMV and the accumulation of PR-proteins (White, 1979). Recently, the involvement of SA in SAR signaling has been clearly demonstrated. Transgenic tobacco that expresses the salicylate hydroxylase gene (nahG) from Pseudomonas putida (Trevisan) does not accumulate SA in response to pathogen infection, and it shows no SAR gene or resistance expression in the distal portions of the plant (Gaffney et al., 1993). Salicylatehydroxylase catalyzes the conversion of SA to catechol, which has no SAR-inducing activity. Therefore, SA appears to be required for SAR development. More recently, Vernooij et al. (1994) performed grafting experiments using wild-type and salicylate-hydroxylase-expressing plants to test whether SA was a systemic signal. NahG transgenic rootstocks, when inoculated with TMV, could induce SAR in wild-type scion tissue equally as well as wild-type rootstocks inoculated with TMV. In addition, scions that expressed salicylate hydroxylase were unable to become resistant, regardless of the rootstock to which they were grafted. The simplest conclusion is that SA is not the primary long-distance signal required for SAR, but SA must be present for the signal to be transduced into gene expression and resistance.

To determine the general role that SA plays in plant health, we assayed bacterial and fungal disease progression in $\mathrm{NahG}$ and control tobacco and Arabidopsis thaliana L. (Delaney et al., 1994). nahG tobacco plants showed more severe disease symptoms than controls when inoculated with TMV, Pseudomonas syringae pv. tabaci (Wolf and Forster), Cercospora nicotianae (Ell. and Ev.), and Phytophthora parasitica (Dastur). NahG Arabidopsis showed greater disease symptoms compared to the control when inoculated with Pseudomonas syringae pv. tomato (DC 3000) (Okabe) and Peronospora parasitica (Pers.:Fr.). Surprisingly, disease symptoms and pathogen growth occurred on NahG Arabidopsis even when avirulent bacteria or races of the fungus to which Arabidopsis is normally resistant were used. 
These results underscore the importance that SA and SA-dependent responses play in plant health.

\section{GENETIC MODIFICATION OF SAR CAN LEAD TO RESISTANT PLANTS}

To genetically dissect the signal transduction mechanism leading to SAR, we isolated mutants of Arabidopsis with altered SAR gene expression (Lawton et al., 1993; Uknes et al., 1993c). Plants that cannot induce SAR gene expression and resistance in response to pathogens or chemical treatment are called "nims" (no immunity). Plants that have high constitutive SAR gene expression and resistance are called "cims" (constitutive immunity). cim Arabidopsis fall into two categories: plants with lesions that simulate disease (lsd) (Dietrich et al., 1994) and plants with no obvious macroscopic phenotype. $l s d$ mutants are similar to other so-called lesion mimics of important crop species such as maize (Zea mays L.) and wheat (Triticum aestivum L.) (Walbot et al., 1983). Such mutants may help us understand the processes involved in disease resistance.

\section{CONCLUSION}

SAR appears to be a ubiquitous higher-plant defense response. SAR is tightly correlated with the expression of specific genes that, when expressed constitutively via strong promoters or genetic alteration ( cim), confer resistance to disease. Furthermore, when SAR is eliminated, due to the obliteration of an essential signal (SA), generalized severe disease susceptibility occurs. Therefore, SAR appears to be an essential component of the defenses that ensure plant health in nature.

\section{Literature Cited}

Alexander, D., R.M. Goodman, M. Gut-Rella, C. Glascock, K. Weymann, L. Friedrich, D. Maddox, P. Ahl Goy, T. Luntz, E. Ward, and J. Ryals. 1993. Increased tolerance to two oomycete pathogens in transgenic tobacco expressing pathogenesis-related protein 1a. Proc. Natl. Acad. Sci. USA 90:7327-7331.

Broglie, K., I. Chet, M. Holliday, R. Cressman, P. Biddle, C. Knowlton, C.J. Mauvais, and R. Broglie. 1991. Transgenic plants with enhanced resistance to the fungal pathogen Rhizoctonia solani. Science 254:1194-1197.

Chester, K.S. 1933. The problem of acquired physiological immunity in plants. Quarterly Rev. Biol. 8:275-324.

Dean, R.A. and J. Kuc. 1988. Rapid lignification in response to wounding and infection as a mechanism for induced systemic protection in cucumber. Physiol. Mol. Plant Pathol. 31:69-81.

Delaney, T., S. Uknes, B. Vernooij, L. Friedrich, K. Weymann, D. Negrotto, T. Gaffney, M. Gut-Rella, H. Kessmann, E. Ward, and J. Ryals. 1994. A central role of salicylic acid in plant disease resistance. Science 266:12471250

Dietrich, R., T. Delaney, S. Uknes, E. Ward, J. Ryals, and J. Dangl. 1994.
Arabidopsis mutants simulating disease resistance response. Cell 77:565577.

Gaffney, T., L. Friedrich, B. Vernooij, D. Negrotto, G. Nye, S. Uknes, E. Ward, H. Kessmann, and J. Ryals. 1993. Requirement of salicylic acid for the induction of systemic acquired resistance. Science 261:754-756.

Kessmann, H., T. Staub, C. Hofmann, T. Maetzke, J. Herzog, E. Ward, S. Uknes, and J. Ryals. 1994. Induction of systemic acquired disease resistance in plants by chemicals. Annu. Rev. Phytopathol. 32:439-459.

Kuc, J. 1982. Induced immunity to plant disease. BioScience 32:854-860.

Lamb, C.J., M.A. Lawton, M. Dron, and R.A. Dixon. 1989. Signals and transduction mechanisms for activation of plant defenses against microbial attack. Cell 56:215-224.

Lawton, K., S. Uknes, L. Friedrich, T. Gaffney, D. Alexander, R. Goodman, J.P. Métraux, H. Kessmann, P. Ahl-Goy, M. Gut Rella, E. Ward, and J. Ryals. 1993. The molecular biology of systemic acquired resistance, p. 422-432. In: B. Fritig and M. Legrand (eds.). Mechanisms of defence responses in plants. Kluwer Academic Publishers, Dordrecht, The Netherlands.

Métraux, J.P., L. Streit, and T. Staub. 1988. A pathogenesis-related protein in cucumber is a chitinase. Physiol. Mol. Plant Pathol. 33:1-9.

Ross, A.F. 1961a. Localized acquired resistance to plant virus infection in hypersensitive hosts. Virology 14:329-339.

Ross, A.F. 1961b. Systemic acquired resistance induced by localized virus infections in plants. Virology 14:340-358.

Stein, B.D., K.L. Klomparens, and R. Hammerschmidt. 1993. Histochemistry and ultrastructure of the induced resistance response of cucumber plants to Colletotrichum lagenarium. J. Phytopathol. 137:177-188.

Uknes, S., S. Dincher, L. Friedrich, D. Negrotto, S. Williams, H. ThompsonTaylor, S. Potter, E. Ward, and J. Ryals. 1993a. Regulation of pathogenesisrelated protein 1-a gene expression in tobacco. Plant Cell 5:159-169.

Uknes, S., K. Lawton, E. Ward, T. Gaffney, L. Friedrich, D. Alexander, R. Goodman, J.-P. Metraux, H. Kessmann, P. Ahl Goy, M. Gut Rella, and J. Ryals. 1993c. The molecular biology of systemic acquired resistance, p. 110. In: P. Gresshoff (ed.). Plant responses to the environment. CRC Press, Boca Raton, Fla.

Uknes, S., B. Mauch-Mani, M. Moyer, S. Potter, S. Williams, S. Dincher, D. Chandler, A. Slusarenko, E. Ward, and J. Ryals. 1992. Acquired resistance in Arabidopsis. Plant Cell 4:645-656.

Uknes, S., A. Winter, T. Delaney, B. Vernooij, L. Friedrich, A. Morse, S. Potter, E. Ward, and J. Ryals. 1993b. Biological induction of systemic acquired resistance in Arabidopsis. Mol. Plant Microbe Interaction 6:692-698.

Van Loon, L.C. and J.F. Antoniw. 1982. Comparison of the effects of salicylic acid and ethephon with virus-induced hypersensitivity and acquired resistance in tobacco. Neth. J. Plant Pathol. 88:237-256.

Vernooij, B., L. Friedrich, A. Morse, R. Reist, R. Kolditz-Jawhar, E. Ward, S. Uknes, H. Kessmann, and J. Ryals. 1994. A novel long distance signal is required for systemic acquired resistance. Plant Cell 6:959-965.

Walbot, V., D.A. Hoisington, and M.G. Neuffer . 1983. Disease lesion mimics in maize, p. 431-442. In: T. Kosuge and C. Meredith (ed.). Genetic engineering of plants. Plenum, New York

Ward, E.R., S.J. Uknes, S.C. Williams, S.S. Dincher, D.L. Wiederhold, D.C. Alexander, P. Ahl-Goy, J.-P. Métraux, and J.A. Ryals. 1991. Coordinate gene activity in response to agents that induce systemic acquired resistance. Plant Cell 3:1085-1094.

White, R.F. 1979. Acetylsalicylic acid (aspirin) induces resistance to tobacco mosaic virus in tobacco. Virology 99:410-412. 